\title{
BMR
}

\section{Analysis of allelic variants of $r d x A$ associated with metronidazole resistance in Helicobacter pylori: detection of common genotypes in $r d x A$ by multiplex allele-specific polymerase chain reaction}

\author{
T.R.P. Butlop, N.T.N. Mungkote and N.T.R. Chaichanawongsaroj \\ Department of Transfusion Medicine and Clinical Microbiology, \\ Faculty of Allied Health Sciences, Chulalongkorn University, \\ Pathumwan, Bangkok, Thailand \\ Corresponding author: N.T.R. Chaichanawongsaroj \\ E-mail: nuntaree@gmail.com
}

Genet. Mol. Res. 15 (3): gmr.15038674

Received March 30, 2016

Accepted May 2, 2016

Published September 2, 2016

DOI http://dx.doi.org/10.4238/gmr.15038674

Copyright $(2016$ The Authors. This is an open-access article distributed under the terms of the Creative Commons Attribution ShareAlike (CC BY-SA) 4.0 License

\begin{abstract}
Resistance to metronidazole (Mtz) in Helicobacter pylori is a major problem worldwide, especially in developing countries. Alterations in Mtz nitroreductase enzymes, such as oxygen-insensitive NADPH nitroreductase (RdxA) and NADPH flavin oxidoreductase (FrxA), are the major contributing factors for this resistance. In this study, $r d x A$ and frxA were amplified, sequenced, and analyzed in 34 Mtz-resistant $H$. pylori isolates (MIC $\geq 8 \mu \mathrm{g} / \mathrm{mL}$ ) using multiple allelespecific polymerase chain reaction (MAS-PCR); this method was developed to target the most common genotypes of $r d x A$ in $H$. pylori. In this study, the $r d x A$ and frx $A$ genes in Mtz-resistant $H$. pylori strains
\end{abstract}


displayed a large number of point mutations. The $r d x A$ and frxA genes of Mtz-resistant clinical isolates showed a higher percentage of missense mutations ( 97.1 and $78.6 \%$, respectively) compared to 26695 reference strains; additionally, missense mutations were more common than frameshift (20.6 and 32.1\%) and nonsense mutations (8.8 and 10.7\%, respectively) in these genes. The most common missense mutations in $r d x A$ were D $59 \mathrm{~N}(94.1 \%)$, T $31 \mathrm{E}(88.2 \%)$, and R $131 \mathrm{~K}(85.3 \%)$. The most common missense mutations in frxA were F $72 \mathrm{~S}(57.1 \%), \mathrm{G} 73 \mathrm{~S}$ (57.1\%), and C $193 \mathrm{~S}$ (53.6\%). The developed MAS primers, specific to position 175 and 392 of $r d x A$, successfully amplified the common alleles and distinguished the variants. MAS-PCR could be a useful tool for epidemiological studies of $H$. pylori, associated with Mtz resistance. $r d x A$ variants must be screened in order to ensure the effectiveness of Mtz-based H. pylori therapies in developing countries.

Key words: Helicobacter pylori; Metronidazole; $r d x A$ gene; frxA gene; MAS-PCR

\section{INTRODUCTION}

Helicobacter pylori has been recognized as the major cause of peptic ulcer and gastritis, and a primary risk factor for various types of gastric cancer, including gastric adenocarcinoma and mucosa-associated lymphoid tissue lymphoma (Eidt and Stolte, 1995; Wisniewski and Peura, 1997). Approximately 50\% of the world population are infected with H. pylori; however, the rate of infection is variable among countries: for example, the infection rate is $62 \%$ in China, $27.5 \%$ in Japan, $65.6 \%$ in Vietnam, and $45.9 \%$ in Thailand (Shi et al., 2008; Nguyen et al., 2010; Hirayama et al., 2014; Uchida et al., 2015). Metronidazole (Mtz) is a standard triple therapy recommended by the 1994 National Institute of Health Consensus for H. pylori eradication (NIH Consensus Development Panel on Helicobacter pylori in Peptic Ulcer Disease, 1994). Mtz is also a critical component of hybrid, concomitant, quadruple, and sequential therapies for H. pylori infection (Egan et al., 2007). Reduction of the nitro group in Mtz gives rise to cytotoxic radicals that are essential for the mediation of DNA strand breakage, helix destabilization, unwinding, and ultimately, cell death (Edwards, 1993; Scarpignato, 2004). However, several countries have seen a marked increase in the prevalence of Mtz resistance, leading to treatment failure. Previous studies have demonstrated a geographic variance in the rate of Mtz resistance (44.1\% in America, 92.4\% in Africa, 37.1\% in Asia, and $17.0 \%$ in Europe) (De Francesco et al., 2010). Mtz resistance is predominantly dependent on the mutational inactivation of $r d x A$, which encodes an oxygen-insensitive NADPH nitroreductase (Goodwin et al., 1998). Mutations in frxA, which encodes the NADPH flavin oxidoreductase, have also been shown to enhance Mtz resistance in the presence of $r d x A$ mutations (Kwon et al., 2000; Binh et al., 2015). However, intact $r d x A$ or frxA have also been implicated in the development of Mtz resistance in H. pylori strains; conversely, mutations in $r d x A$ or frx $A$ have been identified in both Mtz-sensitive and -resistant isolates (Matteo et al., 2006). The exact role of genomic variants in the acquisition of Mtz resistance in $H$. pylori remains controversial. A previous analysis of the $r d x A$ and frxA nucleotide sequences of individual resistant and

Genetics and Molecular Research 15 (3): gmr.15038674 
sensitive strains revealed a large number of point mutations (Mirzaei et al., 2014). Frameshift and nonsense mutations in $r d x A$ and frx $A$ genes are believed to cause Mtz resistance, affecting the efficiency of H. pylori eradication (Alfizah et al., 2014). Molecular characterization of sensitive and resistant strains has yielded information that could be useful in assessing the genotypic association with Mtz resistance, phylogenetic evolution, and epidemiological study. Some of the molecular techniques used to study genotypic variations include sequencing, rapid amplified polymorphic DNA (RAPD), polymerase chain reaction-restriction fragment length polymorphism (PCR-RFLP), real-time-PCR, denaturing gel gradient electrophoresis, ribotyping, and pulse field gel electrophoresis; however, these methods are sophisticated (requiring high-end instrumentation), time-consuming, and expensive (Kansau et al., 1996; Tee, 1997; Sjunnesson et al., 2003; Rimbara et al., 2013).

Multiplex allele-specific PCR (MAS-PCR) has been previously used in the detection of point mutations, such as single nucleotide polymorphisms associated with genetic diseases and antibiotic resistance in infectious organisms, in various biomedical applications (Bagheri and Rad, 2011; Chia et al., 2012). The perfect match of a 3'-allele-specific primer with the DNA template yields an amplification product, while a mismatch inhibits DNA polymerase elongation, which in turn inhibits the development of an amplification product. In this study, the genomic sequence of $r d x A$ and frxA was analyzed in $34 \mathrm{Mtz}$-resistant $H$. pylori clinical isolates from Thailand and the results compared to the findings of previous studies. Moreover, the nucleotide sequence of $r d x A$ was determined in 30 Campylobacter-like organism-positive (CLO+) samples. The most common genomic variants of $r d x A$ were determined by MAS-PCR.

\section{MATERIAL AND METHODS}

\section{Bacterial strains and growth conditions}

Thirty four Mtz-resistant $H$. pylori clinical isolates (MIC $\geq 8 \mu \mathrm{g} / \mathrm{mL}$ ), provided by Dr. Ratha-Korn Vilaichone (Associate Professor, Division of Gastroenterology, Department of Medicine, Thammasat University Hospital, Pathumthani, Thailand), were incubated in 1 $\mathrm{mL}$ tryptic soy broth with $15 \%$ glycerol at $-80^{\circ} \mathrm{C}$. H. pylori ATCC 51932 was cultured on brain heart infusion agar supplemented with $5 \%(\mathrm{v} / \mathrm{v})$ sheep blood, and incubated in a microaerobic atmosphere $\left(10 \% \mathrm{CO}_{2}, 5 \% \mathrm{O}_{2}\right)$ at $37^{\circ} \mathrm{C}$ for 5 days. Thirty samples that were positive for the CLO test, and which were confirmed to be H. pylori by PCR (in a previous study), were obtained from the Department of Gastroenterology, Faculty of Medicine, Chulalongkorn University (Champathai et al., 2014).

\section{DNA extraction}

Genomic DNA was extracted from all H. pylori strains using the Wizard Genomic DNA Purification Kit (Promega, Madison, WI, USA) according to the manufacturer instructions. DNA from $\mathrm{CLO}+$ samples was extracted using the boiling method. Briefly, agar of each CLO+ sample was boiled with $300 \mu \mathrm{L}$ deionized water in a $1.5-\mathrm{mL}$ microtube for $10 \mathrm{~min}$. The suspension was centrifuged at $7000 \mathrm{~g}$ for $5 \mathrm{~min}$ and $200 \mu \mathrm{L}$ the supernatant was transferred to a new tube. The supernatant was incubated with $600 \mu \mathrm{L}$ cold absolute ethanol at $-80^{\circ} \mathrm{C}$ for $10 \mathrm{~min}$ and subsequently centrifuged at $7000 \mathrm{~g}$ for $2 \mathrm{~min}$. The pellet was washed with $70 \%$ ethanol, air dried prior to resuspension in $100 \mu \mathrm{L}$ TE buffer, and stored at $-20^{\circ} \mathrm{C}$ until further use.

Genetics and Molecular Research 15 (3): gmr.15038674 


\section{PCR amplification of $r d x A$ and $f r x A$}

The $r d x A$ gene was amplified by PCR in a $50-\mu \mathrm{L}$ mixture containing $1 \mathrm{X}$ PCR buffer (10 mM Tris-HCl, $\left.50 \mathrm{mM} \mathrm{KCl}, 1.5 \mathrm{mM} \mathrm{MgCl}_{2}\right), 0.2 \mathrm{mM}$ dNTPs, $1.25 \mathrm{U}$ Taq DNA polymerase (New England Biolabs, Ipswich, MA, USA), $0.5 \mu \mathrm{M}$ each of the $r d x A$ primers (5'-GCAGGAGCATCAGATAGTTCT-3' and 5'-GGGATTTTATTGTATGCTACAA-3'), and 100 ng DNA template (Yang et al., 2004). The PCR conditions were set as follows: denaturation at $92^{\circ} \mathrm{C}$ for $2 \mathrm{~min} ; 40$ cycles of denaturation at $95^{\circ} \mathrm{C}$ for $60 \mathrm{~s}$, annealing at $50^{\circ} \mathrm{C}$ for $60 \mathrm{~s}$, and extension at $72^{\circ} \mathrm{C}$ for $60 \mathrm{~s}$; and a final extension at $72^{\circ} \mathrm{C}$ for 10 min. The 886 -bp PCR product was detected by electrophoresing on a $1.5 \%$ agarose gel using the TBE buffer (45 mM Tris-borate, $1 \mathrm{mM}$ EDTA; pH 8.0) at $100 \mathrm{~V}$. The gel was stained with ethidium bromide and visualized under a UV transilluminator (G: BOX, SYNGENE, USA).

frx $A$ was amplified in a 50- $\mu$ L PCR mixture containing $1 X$ PCR buffer $(10 \mathrm{mM}$ Tris$\mathrm{HCI}, 50 \mathrm{mMKCl}, 1.5 \mathrm{mMMgCl}_{2}$ ), $0.2 \mathrm{mMdNTPs}, 1.25 \mathrm{UTaqDNApolymerase}$ (New England Biolabs), and $0.5 \mu \mathrm{M}$ each of the frxA primers (5'-GGATATGGCAGCCGTTTATCATT-3' and 5'-GAATAGGCATCATTTAAGAGATTA-3') (Yang et al., 2004). The PCR conditions were set as follows: denaturation at $92^{\circ} \mathrm{C}$ for $2 \mathrm{~min} ; 40$ cycles of denaturation at $95^{\circ} \mathrm{C}$ for $60 \mathrm{~s}$, annealing at $52^{\circ} \mathrm{C}$ for $60 \mathrm{~s}$, and extension at $72^{\circ} \mathrm{C}$ for $60 \mathrm{~s}$; and a final extension at $72^{\circ} \mathrm{C}$ for $10 \mathrm{~min}$. The 780 -bp PCR product was detected by electrophoresing on a $1.5 \%$ agarose gel, as described previously in this section.

\section{DNA sequence determination, alignment, and phylogenetic analysis}

The PCR fragments were purified and sequenced by Bioneer (Daejeon, Korea). The $r d x A$ and $f r x A$ sequences were analyzed using the Basic Local Alignment Search Tool (BLAST; http://blast.ncbi.nlm.nih.gov/Blast.cgi) (Altschul et al., 1990) and aligned with the H. pylori 26695 reference strain using BioEdit (http://www.mbio.ncsu.edu/BioEdit/bioedit. html). The obtained sequence was phylogenetically analyzed using BioEdit (2013).

\section{Allele-specific primer design}

Allele-specific (AS) primers were designed to detect the most common genotype of $r d x A$. The 3' terminal base of each AS primer was adapted to a common allele. Amplification was performed with $r d x A$ forward and reverse primers. The primers were synthesized and supplied by BioDesign Co., Ltd. (Pathumthani, Thailand). The primer sequences are listed in Table 1.

\begin{tabular}{|c|c|c|c|}
\hline Primer & Sequence & Concentration $(\mu \mathrm{M})$ & Product length (bp) \\
\hline$r d x A-R$ & 5' GCAGGAGCATCAGATAGTTCT 3' & 0.4 & \multirow{2}{*}{886} \\
\hline$r d x A-F$ & 5' GGGATTTTATTGTATGCTACAA 3' & 0.2 & \\
\hline AS59-F & 5' GCATTTTGTGATGGTTACTG 3' & 0.2 & 681 \\
\hline$A S 131-F$ & \begin{tabular}{|l} 
5' TCAACCACAGCATGCAAAG 3' \\
\end{tabular} & 0.1 & 463 \\
\hline
\end{tabular}

Genetics and Molecular Research 15 (3): gmr.15038674 


\section{MAS-PCR}

Common alleles of $r d x A$, associated with Mtz resistance in H. pylori, were determined by MAS-PCR, in a total reaction volume of $50 \mu \mathrm{L}$ containing $1 \mathrm{X}$ PCR buffer $(10 \mathrm{mM}$ Tris$\mathrm{HCl}, 50 \mathrm{mM} \mathrm{KCl}, 1.5 \mathrm{mM} \mathrm{MgCl}$ ), $0.2 \mathrm{mM}$ dNTPs, $1.5 \mathrm{U}$ Taq DNA polymerase (New England Biolabs), and 100 ng DNA template. Optimized concentrations of all primers are summarized in Table 1. The reaction was performed under the following conditions: an initial denaturation at $95^{\circ} \mathrm{C}$ for $10 \mathrm{~min} ; 10$ cycles of denaturation at $95^{\circ} \mathrm{C}$ for $30 \mathrm{~s}$, annealing at $60^{\circ} \mathrm{C}$ for $45 \mathrm{~s}$, extension at $72^{\circ} \mathrm{C}$ for $60 \mathrm{~s} ; 20$ cycles of denaturation at $95^{\circ} \mathrm{C}$ for $30 \mathrm{~s}$, annealing at $64^{\circ} \mathrm{C}$ for $45 \mathrm{~s}$, extension at $72^{\circ} \mathrm{C}$ for $60 \mathrm{~s} ; 20$ cycles of denaturation at $95^{\circ} \mathrm{C}$ for $30 \mathrm{~s}$, annealing at $55^{\circ} \mathrm{C}$ for $45 \mathrm{~s}$, extension at $72^{\circ} \mathrm{C}$ for $60 \mathrm{~s}$; and a final extension at $72^{\circ} \mathrm{C}$ for $10 \mathrm{~min}$. The $886-, 681-$, and 463-bp MAS-PCR products were analyzed by electrophoresing on a $1.5 \%$ agarose gel.

\section{RESULTS}

\section{Effect of $r d x A$ and $f r x A$ mutations on Mtz resistance in $H$. pylori}

The effect of mutations in $r d x A$ and $f r x A$ on Mtz resistance in $H$. pylori was analyzed in $34 \mathrm{H}$. pylori clinical strains and 26695 reference strains (Figures 1 and 2). Missense and frameshift mutations were observed in $r d x A$ in $33(97.1 \%)$ and $7(20.6 \%)$ strains, respectively. On the other hand, truncated $r d x A$ was detected in 3 strains $(8.8 \%)$. Missense mutations at positions $1,4,10,21,37,41,74,79,91,92,104,106,113,115,116,176,183,193$, and 203 in $r d x A$ have not been reported in published Mtz-resistant strains. Additionally, frameshift mutations at positions $4,6,9,71,72,79$, and 182 and nonsense mutations at positions 2 and 52 were unique to our study. Analysis of frx $A$ mutations revealed $78.6 \%$ missense mutations, $32.1 \%$ frameshift mutations, and $10.7 \%$ nonsense mutations (Figure 2). Missense mutations at positions $1,27,35,37,39,60,65,66,67,70,94,131,154,177,200$, and 206, a frameshift mutation at position 109 , and a nonsense mutation at position 30 were unique to our study. The $r d x A$ and $f r x A$ genes were non-mutated in 1 and 3 Mtz-resistant isolates, respectively.

Phylogenetic analysis of the $r d x A$ and frx $A$ trees (Figures 3 and 4) provided further evidence of the high genomic diversity found at the nucleotide level. The topologies of both trees were different, and the strains did not cluster significantly, based on the $r d x A$ and frx $A$ sequences.

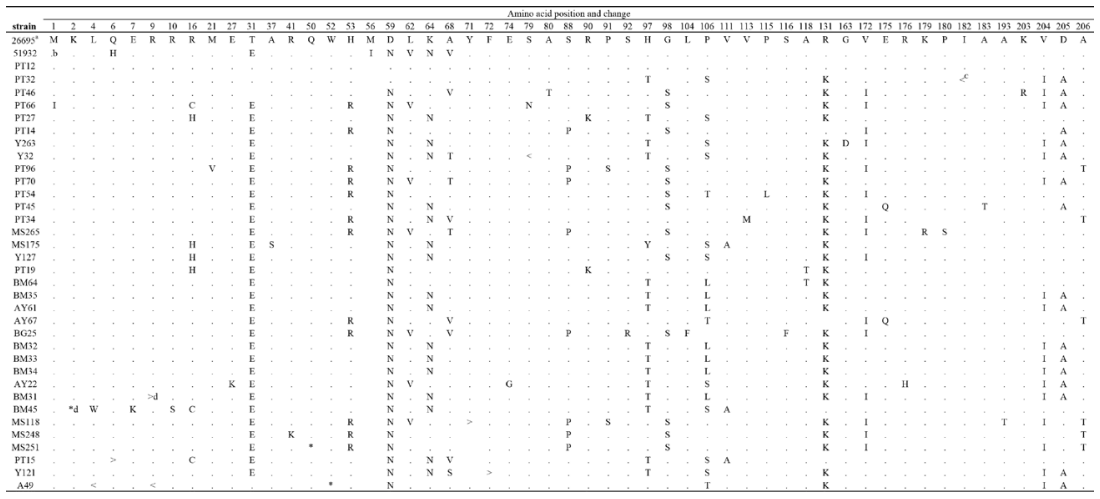

Figure 1. Alignment of RdxA from 34 Mtz-resistant Helicobacter pylori clinical isolates and ATCC 51932.

Genetics and Molecular Research 15 (3): gmr.15038674 
T.R.P. Butlop et al.

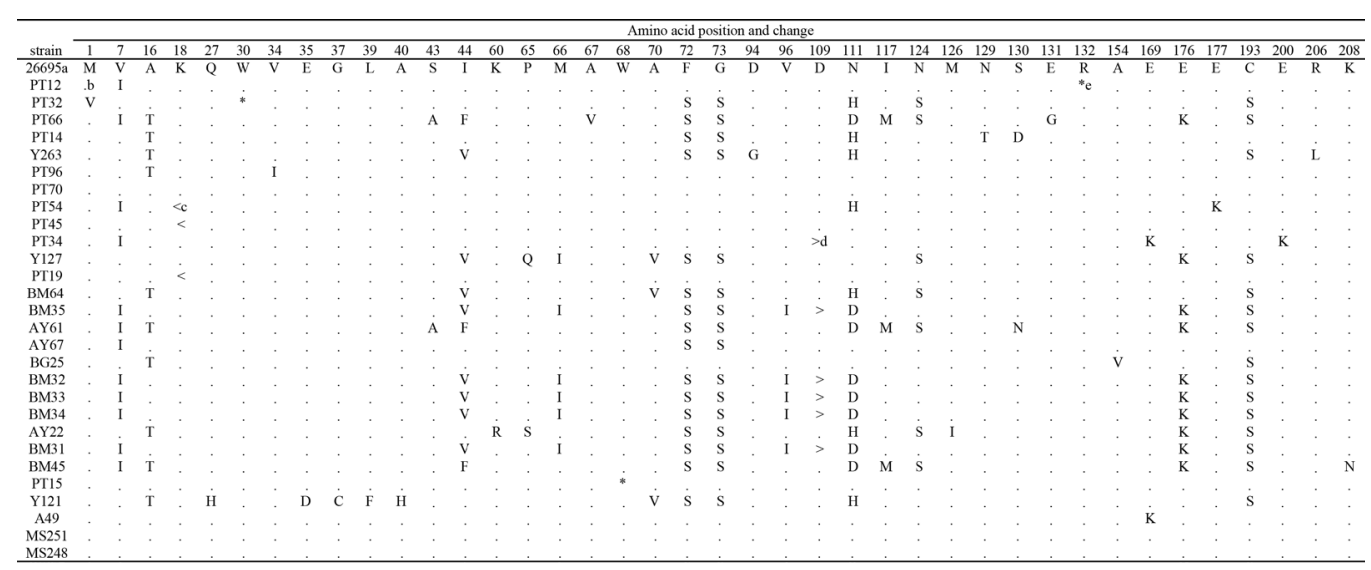

Figure 2. Alignment of FrxA from 28 Mtz-resistant Helicobacter pylori clinical isolates.

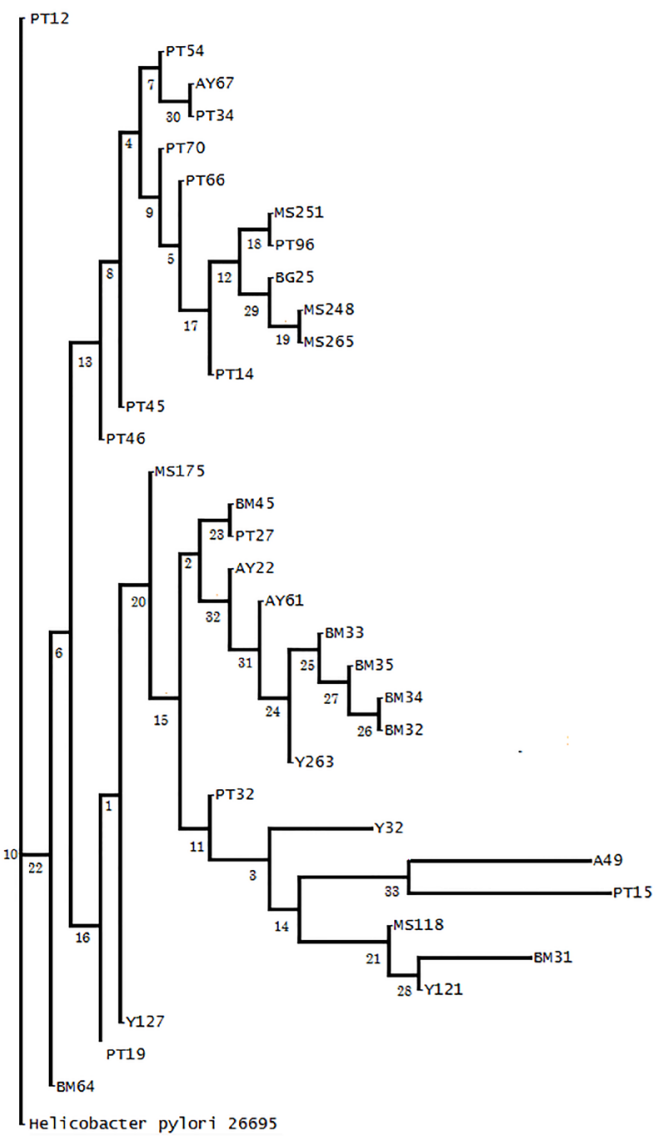

Figure 3. Phylogenetic tree generated from nucleotide sequences of $r d x A$ from 34 Mtz-resistant Helicobacter pylori.

Genetics and Molecular Research 15 (3): gmr.15038674 


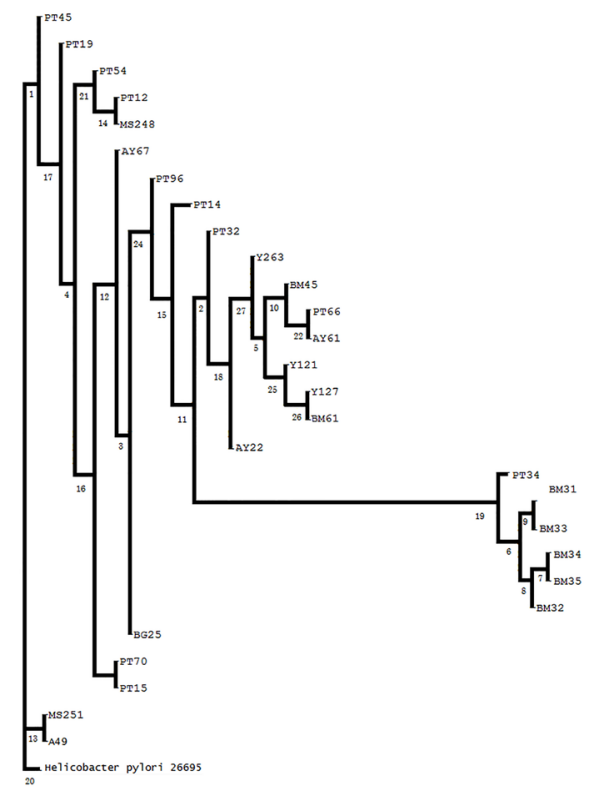

Figure 4. Phylogenetic tree generated from nucleotide sequences of frxA from $28 \mathrm{Mtz}$-resistant Helicobacter pylori.

\section{Analysis of genomic variants of $r d x A$ in Mtz-resistant $H$. pylori isolates and CLO+ samples}

The frequency of $r d x A$ missense mutations in the 34 Mtz-resistant $H$. pylori isolates and $30 \mathrm{CLO}+$ samples is summarized in Table 2. The most common $r d x A$ alleles in Mtzresistant $H$. pylori and CLO+ samples were A (94.1\%) and A (96.7\%) at position 59 [Asp $\rightarrow$ Asn, G (175) $\rightarrow$ A], GA (88.2\%) and GA (80.0\%) at position 31 [Thr $\rightarrow$ Glu, AC $(91,92) \rightarrow$ $\mathrm{GA}$ ], and A (85.3\%) and A (76.7\%) at position 131 [Arg $\rightarrow$ Lys, G (392) $\rightarrow$ A].

Table 2. Genetic variants of $r d x A$ missense mutations in 34 Mtz-resistant Helicobacter pylori isolates and 30 positive CLO test samples.

\begin{tabular}{|c|c|c|c|c|c|c|c|c|c|c|c|}
\hline $\begin{array}{l}\text { Type of } \\
\text { mutation }\end{array}$ & $\begin{array}{l}\text { Nucleotide } \\
\text { position }\end{array}$ & $\begin{array}{l}\text { Mtz-resistant } \\
\text { H. pylori }(\%)\end{array}$ & $\begin{array}{c}\text { Positive CLO } \\
\text { test samples (\%) }\end{array}$ & $\begin{array}{l}\text { Type of } \\
\text { mutation }\end{array}$ & $\begin{array}{c}\text { Nucleotide } \\
\text { position }\end{array}$ & $\begin{array}{c}\text { Mtz-resistant } H . \\
\text { pylori }(\%)\end{array}$ & $\begin{array}{l}\text { Positive CLO test } \\
\text { samples }(\%)\end{array}$ & \begin{tabular}{|l|} 
Type of \\
mutation
\end{tabular} & $\begin{array}{c}\text { Nucleotide } \\
\text { position }\end{array}$ & $\begin{array}{l}\text { Mtz-resistant } \\
\text { H. pylori }(\%)\end{array}$ & $\begin{array}{c}\text { Positive CLO } \\
\text { test samples }(\%)\end{array}$ \\
\hline $\mathrm{G} \rightarrow \mathrm{A}$ & 175 & 94.1 & 96.7 & $\mathrm{~T} \rightarrow \mathrm{G}$ & 11 & 2.9 & 0 & $\mathrm{G} \rightarrow \mathrm{A}$ & 29 & 0 & $\frac{36.7}{36 .}$ \\
\hline $\mathrm{AC} \rightarrow \mathrm{GA}$ & 91,92 & 88.2 & 80 & $A \rightarrow T$ & 30 & 2.9 & 0 & $\mathrm{~A} \rightarrow \mathrm{G}$ & 106 & 0 & 36.7 \\
\hline $\mathrm{G} \rightarrow \mathrm{A}$ & 392 & 85.3 & 76.7 & $\mathrm{G} \rightarrow \mathrm{A}$ & 19 & 2.9 & 10 & $\mathrm{~A} \rightarrow \mathrm{G}$ & 17 & 0 & 26.7 \\
\hline$A \rightarrow C$ & 614 & 50 & 33.3 & $\mathrm{~A} \rightarrow \mathrm{G}$ & 61 & 2.9 & 0 & $\mathrm{C} \rightarrow \mathrm{T}$ & 548 & 0 & 10 \\
\hline $\mathrm{G} \rightarrow \mathrm{A}$ & 610 & 50 & 23.3 & $\mathrm{G} \rightarrow \mathrm{A}$ & 79 & 2.9 & 0 & $\mathrm{C} \rightarrow \mathrm{G}$ & 60 & 0 & 6.7 \\
\hline$A \rightarrow T$ & 192 & 47.1 & 36.7 & $\begin{array}{l}\mathrm{G} \rightarrow \mathrm{A} \\
\mathrm{G} \rightarrow \mathrm{T}\end{array}$ & 109 & 2.9 & 0 & $\mathrm{AT} \rightarrow \mathrm{GA}$ & 106,107 & 0 & 6.7 \\
\hline $\mathrm{CAC} \rightarrow \mathrm{ACG}$ & $289,290,291$ & 47.1 & 20 & $\mathrm{GG} \rightarrow \mathrm{AA}$ & 122,123 & 2.9 & 0 & $\mathrm{~A} \rightarrow \mathrm{C}$ & 18 & 0 & 3.3 \\
\hline $\mathrm{G} \rightarrow \mathrm{A}$ & 514 & 44.1 & 33.3 & $\mathrm{G} \rightarrow \mathrm{T}$ & 202 & 2.9 & 0 & $\mathrm{~A} \rightarrow \mathrm{C}$ & 21 & 0 & 3.3 \\
\hline $\mathrm{G} \rightarrow \mathrm{A}$ & 292 & 38.2 & 20 & $\mathrm{~A} \rightarrow \mathrm{G}$ & 221 & 2.9 & 0 & $\mathrm{~A} \rightarrow \mathrm{C}$ & 24 & 0 & 3.3 \\
\hline $\mathrm{A} \rightarrow \mathrm{G}$ & 158 & 35.3 & 16.7 & $\mathrm{G} \rightarrow \mathrm{A}$ & 236 & 2.9 & 0 & $\mathrm{AA} \rightarrow \mathrm{CC}$ & 22,24 & 0 & 3.3 \\
\hline $\mathrm{C} \rightarrow \mathrm{T}$ & 316 & 29.4 & 10 & $\mathrm{G} \rightarrow \mathrm{A}$ & 238 & 2.9 & 0 & $\mathrm{AAA} \rightarrow \mathrm{CTC}$ & $22,23,24$ & 0 & 3.3 \\
\hline $\mathrm{T} \rightarrow \mathrm{C}$ & 262 & 23.5 & 16.7 & $\mathrm{C} \rightarrow \mathrm{G}$ & 276 & 2.9 & 0 & $\mathrm{AG} \rightarrow \mathrm{CA}$ & 28,29 & 0 & 3.3 \\
\hline $\mathrm{CC} \rightarrow \mathrm{TT}$ & 316,317 & 20.6 & 10 & $C \rightarrow T$ & 289 & 2.9 & 3.3 & $\begin{array}{l}\mathrm{A} \rightarrow \mathrm{C} \rightarrow \mathrm{A} \\
\mathrm{A} \rightarrow \mathrm{s}\end{array}$ & 77 & 0 & 3.3 \\
\hline $\mathrm{G} \rightarrow \mathrm{A}$ & 616 & 17.6 & 26.7 & $\mathrm{CC} \rightarrow \mathrm{TT}$ & 310,312 & 2.9 & 0 & $\mathrm{G} \rightarrow \mathrm{A}$ & 89 & 0 & 3.3 \\
\hline $\mathrm{T} \rightarrow \mathrm{G}$ & 184 & 17.6 & 6.7 & $\mathrm{G} \rightarrow \mathrm{A}$ & 337 & 2.9 & 0 & $\mathrm{C} \rightarrow \mathrm{T}$ & 117 & 0 & 3.3 \\
\hline $\mathrm{C} \rightarrow \mathrm{T}$ & 203 & 14.7 & 10 & $\mathrm{C} \rightarrow \mathrm{T}$ & 344 & 2.9 & 0 & $\begin{array}{l}\mathrm{CG} \rightarrow \mathrm{TA} \\
\end{array}$ & 114,145 & 0 & 3.3 \\
\hline $\mathrm{G} \rightarrow \mathrm{A}$ & 47 & 11.8 & 0 & $\mathrm{C} \rightarrow \mathrm{T}$ & 347 & 2.9 & 0 & $\mathrm{C} \rightarrow \mathrm{A}$ & 152 & 0 & 3.3 \\
\hline $\mathrm{C} \rightarrow \mathrm{A}$ & 316 & 8.8 & 6.7 & $\mathrm{G} \rightarrow \mathrm{A}$ & 448 & 2.9 & 0 & $\mathrm{AT} \rightarrow \mathrm{CG}$ & 308,309 & 0 & 3.3 \\
\hline$T \rightarrow C$ & 332 & 8.8 & 3.3 & $\mathrm{G} \rightarrow \mathrm{A}$ & 527 & 2.9 & 0 & $\mathrm{C} \rightarrow \mathrm{G}$ & 316 & 0 & 3.3 \\
\hline $\mathrm{C} \rightarrow \mathrm{T}$ & 46 & 8.8 & 0 & $\mathrm{~A} \rightarrow \mathrm{G}$ & 536 & 2.9 & 0 & G $\rightarrow \mathrm{A}$ & 367 & 0 & 3.3 \\
\hline $\mathrm{G} \rightarrow \mathrm{A}$ & 202 & 8.8 & 0 & $\mathrm{C} \rightarrow \mathrm{T}$ & 538 & 2.9 & 0 & G $\rightarrow \mathrm{T}$ & 427,429 & 0 & 3.3 \\
\hline $\mathrm{G} \rightarrow \mathrm{A}$ & 269 & 5.9 & 23.3 & $\mathrm{G} \rightarrow \mathrm{A}$ & 547 & 2.9 & 3.3 & $\mathrm{~T} \rightarrow \mathrm{G}$ & 479 & 0 & 3.3 \\
\hline $\begin{array}{l}\mathrm{G} \rightarrow \mathrm{A} \rightarrow \mathrm{A} \\
\mathrm{G} \rightarrow \mathrm{s}\end{array}$ & 352 & 5.9 & 3.3 & $\underset{G \rightarrow A}{G \rightarrow A}$ & 577 & 2.9 & 0 & \begin{tabular}{|l|l} 
\\
$\mathrm{G} \rightarrow \mathrm{T}$ \\
\end{tabular} & 514,516 & 0 & 3.3 \\
\hline $\mathrm{G} \rightarrow \mathrm{C}$ & 523 & 5.9 & 3.3 & $\mathrm{AA} \rightarrow \mathrm{GG}$ & 608,609 & 2.9 & 0 & $\mathrm{G} \rightarrow \mathrm{A}$ & 525 & 0 & 3.3 \\
\hline $\mathrm{CC} \rightarrow \mathrm{TT}$ & 271,273 & 5.9 & 3.3 & $\mathrm{G} \rightarrow \mathrm{C}$ & 42 & 0 & 46.7 & & & & \\
\hline $\mathrm{G} \rightarrow \mathrm{A}$ & 3 & 2.9 & 0 & $\mathrm{G} \rightarrow \mathrm{A}$ & 168 & 0 & 43.3 & & & & \\
\hline
\end{tabular}

Genetics and Molecular Research 15 (3): gmr.15038674 


\section{MAS-PCR assay to detect common $r d x A$ variants}

The samples were subjected to MAS-PCR using $r d x A$ forward and reverse primers and two AS-primers. The 3'-terminal base was designed to be guanine $(\mathrm{G})$ in both forward ASprimers (AS59-F and AS131-F; at positions 175 and 392, respectively) of the $r d x A$ gene. The MAS-PCR results are summarized in Figure 5. The 3'-end of the AS primer pairs (with their corresponding common alleles) yielded 886-, 681-, and 463-bp strands. The amplification products of AS-primers did not show a 3'-end mismatch. The positive 886-bp band generated by the main $r d x A$ primer was used as the internal control.

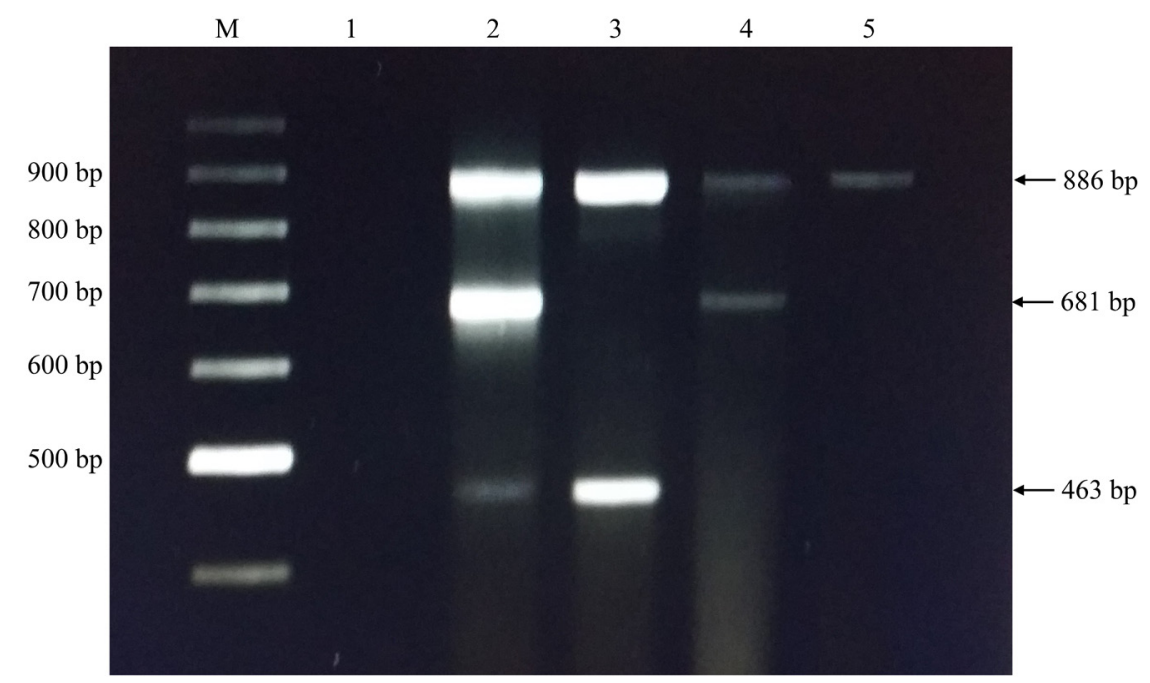

Figure 5. Agarose gel electrophoresis (1.5\%) of MAS-PCR products. Lane $M=100$-bp molecular marker, lane $1=$ negative control, lane $2=r d x A$ without mismatch, lane $3=r d x A$ with amino acid substitution at position 59 , lane $4=r d x A$ with amino acid substitution at position 131 , lane $5=r d x A$ with amino acid substitution at positions 59 and 131 .

\section{DISCUSSION}

Antibiotic resistance is a major obstruction to successful $H$. pylori eradication. Metronidazole is broadly used in the treatment of various infections, and is known to challenge the development of resistance (Jenks and Edwards, 2002). The prevalence of Mtz resistance in H. pylori is higher than that of clarithromycin and amoxicillin, the drugs used to treat H. pylori infections, in many countries, especially developing countries. The resistance rates of $H$. pylori against antibiotics such as Mtz, clarithromycin, and amoxicillin are 26.7, 17.2, and $11.2 \%$, respectively. On the other hand, the resistance rates of $H$. pylori against Mtz, clarithromycin, and amoxicillin are 37.1, 18.9, and 11.6\%, respectively (De Francesco et al., 2010). The evolution of Mtz resistance in $H$. pylori is associated with mutational inactivation of the $r d x A$ and frxA genes (Kwon et al., 2000). The crystal structure of RdxA revealed a homodimer that underwent domain swapping with two molecules of FMN bound at the dimer interface; moreover, a cysteine side chain close to FMN was believed to be involved in the reducing activity (Martínez-Júlvez $\mathrm{M}$ et al., 2012). In this study, all Mtz-resistant $H$. 
pylori clinical isolates harbored several point mutations, such as missense mutation $(97.1 \%)$, frameshift mutations (20.6\%), and nonsense mutations (8.8\%). Previous studies have reported the presence of various missense mutations in $r d x A$ in both susceptible and resistant strains, via amino acid substitutions. The exact genotype patterns of missense mutations contributing to Mtz-resistance remain to be elucidated, while the three most common alleles, adenine at position 175 (Asn59), guanine and adenine at positions 91 and 92 (Glu31), and adenine at position 392 (Lys131), were identified in Mtz-resistant H. pylori clinical strains. These common genotypes were also observed in the CLO+ samples $(96.7,80$, and $76.7 \%$ for alleles $\mathrm{A}, \mathrm{G}$ and $\mathrm{A}$, and $\mathrm{A}$, respectively). These $r d x A$ variants were also unique in susceptible and resistant $H$. pylori strains analyzed in previous studies (Tankovic et al., 2000; Mirzaei et al., 2014), in agreement with our findings. The Mtz-resistant role of these $r d x A$ alleles in $H$. pylori, however, remains to be further elucidated. A phylogenetic tree constructed by Solca et al. (2000), who aligned $30 r d x A$ nucleotide sequences, could not specify the cluster associated with the resistance phenotype, as the resistant and susceptible strains were randomly distributed throughout the dendrogram. In this study, the phylogenetic analysis of $34 \mathrm{rdxA}$ nucleotide sequences obtained from Mtz-resistant $\mathrm{H}$. pylori and $30 \mathrm{CLO}+$ samples revealed high genetic polymorphism. However, no particular characteristic could be clustered by the phylogenetic tree topologies of four $H$. pylori housekeeping genes ( $a t p D, s c o B, g \ln A$, and $\operatorname{rec} A$ ) that arose from frequent recombination, similar to the results obtained in a previous study (Maggi Solca et al., 2001).

Some amino acid substitutions, such as $\operatorname{Arg} 16 \mathrm{His}(\mathrm{N}=4)$, His53Arg $(\mathrm{N}=12)$, Gly163Asp ( $=1)$, Val204Ile $(\mathrm{N}=17)$, Ala206Thr $(\mathrm{N}=6)$, were observed only in resistant isolates, as seen in previous studies (Jeong et al., 2000; Solca et al., 2000; Yang et al., 2004; Matteo et al., 2006). In this study, three Mtz-resistant $H$. pylori isolates contained stop codons (at position 2, 50, and 52). Similarly, Yang et al. (2004) reported a stop codon at position 50 of $r d x A$ in the resistant phenotype. Frameshift mutations producing a truncated RdxA protein were commonly associated with resistance worldwide, with a minimum inhibitory concentration of 64-128 mg/L (Yang et al., 2004; Matteo et al., 2006). We also identified a number of novel missense mutations at positions $1,4,10,21,37,41,74,79,91,92,104,106,113,115,116$, $176,183,193$, and 203. Mutations in RdxA could lead to a loss of reductase activity, which is strongly correlated with Mtz resistance. Mutations such as those affecting residues Arg16, Ser18, Lys20, Asn73, Ile142, Gly162, and Lys200 were expected to decrease the affinity of the apoprotein for the FMN cofactor. Mutations in Leu42, Ser43, Arg41, Gln50, Val55, Met56, Ile142, Gly145, Lys202, and Leu209 residues were theorized to destabilize dimer formation. Additionally, mutations in Cys19, Tyr47, and Cys159 were believed to be associated with the redox function of the enzyme and those in Gly149 and His17 were expected to cause protein destabilization not related to dimerization (Martínez-Júlvez et al., 2012).

In this study, mutations in frxA gene were found in $89.3 \%$ Mtz-resistant $H$. pylori clinical isolates $(78.6 \%$ of missense mutations, $32.1 \%$ frameshift mutations, and $10.7 \%$ nonsense mutations). Mutations in frxA do not contribute significantly to Mtz resistance; however, alterations in this gene enhance the level of Mtz resistance in $r d x A$ mutants (Yang et al., 2004; Binh et al., 2015). The exact role of genomic variants of $r d x A$ and frxA in MTZ resistance in $H$. pylori remains controversial. The structure and mechanism of FrxA mutations, which are also associated with Mtz resistance, have not been elucidated in this study.

MAS-PCR is a rapid, sensitive, specific, inexpensive (using a basic thermal cycler) method, and was therefore used in this study to detect point mutations. In this study, we 
successfully developed a MAS-PCR assay to detect the two most common genetic variants of $r d x A$ in H. pylori. The 3'-terminal base of each AS primer was designed to be guanine, in order to detect the variants at positions 175 and 392. MAS-PCR conditions were optimized to distinguish the common alleles and their variants. This assay could be a useful tool for epidemiological studies and in the future development of molecular typing, which would facilitate the identification of $H$. pylori strains, prediction of antibiotic susceptibility, and public health management (prevention and surveillance).

\section{Conflicts of interest}

The authors declare no conflict of interest.

\section{ACKNOWLEDGMENTS}

Research supported by grants provided by the Rachadaphiseksomphot Endowment Fund (part of the "Strengthen CU's Researcher's Projects") and the 90th Year Chulalongkorn Scholarship. The authors would like to thank Dr. Ratha-Korn Vilaichone (Associate Professor, Division of Gastroenterology, Department of Medicine, Thammasat University Hospital) for providing the H. pylori clinical isolates and Dr. Suthep Gonlchanvit (Professor, Department of Gastroenterology, Faculty of Medicine, Chulalongkorn University) for providing the CLO test samples.

\section{REFERENCES}

Alfizah H, Norazah A, Hamizah R and Ramelah M (2014). Resistotype of Helicobacter pylori isolates: the impact on eradication outcome. J. Med. Microbiol. 63: 703-709.

Altschul SF, Gish W, Miller W, Myers EW, et al. (1990). Basic local alignment search tool. J. Mol. Biol. 215: 403-410. http://dx.doi.org/10.1016/S0022-2836(05)80360-2

Bagheri M and Rad IA (2011). A multiplex allele specific polymerase chain reaction (MAS-PCR) for the detection of factor V Leiden and prothrombin G20210A. Maedica 6: 3-9.

Binh TT, Suzuki R, Trang TT, Kwon DH, et al. (2015). Search for novel candidate mutations for metronidazole resistance in Helicobacter pylori using next-generation sequencing. Antimicrob. Agents Chemother. 59: 2343-2348. http:// dx.doi.org/10.1128/AAC.04852-14

BioEdit (2013). Biological sequence alignment editor written. Available at [www.mbio.ncsu.edu/bioedit/bioedit.html]. Accessed November 12, 2015.

Champathai T, Gonlachanvit S and Chaichanawongsaroj N (2014). Detection of A2143G mutation in 23S rRNA gene associated with clarithromycin resistant Helicobacter pylori by Loop mediated isothermal amplification. J. Chem. Pharm. Res. 6: 148-155.

Chia BS, Lanzas F, Rifat D, Herrera A, et al. (2012). Use of multiplex allele-specific polymerase chain reaction (MASPCR) to detect multidrug-resistant tuberculosis in Panama. PloS One 7: e40456. http://dx.doi.org/10.1371/journal. pone. 0040456

De Francesco V, Giorgio F, Hassan C, Manes G, et al. (2010). Worldwide H. pylori antibiotic resistance: a systematic review. J. Gastrointestin. Liver Dis. 19: 409-414.

Edwards DI (1993). Nitroimidazole drugs - action and resistance mechanisms. I. Mechanisms of action. J. Antimicrob. Chemother. 31: 9-20. http://dx.doi.org/10.1093/jac/31.1.9

Egan BJ, Katicic M, O'Connor HJ and O'Morain CA (2007). Treatment of Helicobacter pylori. Helicobacter 12: 31-37. http://dx.doi.org/10.1111/j.1523-5378.2007.00538.x

Eidt $\mathrm{S}$ and Stolte M (1995). The significance of Helicobacter pylori in relation to gastric cancer and lymphoma. Eur. J. Gastroenterol. Hepatol. 7: 318-321.

Goodwin A, Kersulyte D, Sisson G, Veldhuyzen van Zanten SJ, et al. (1998). Metronidazole resistance in Helicobacter

Genetics and Molecular Research 15 (3): gmr.15038674 
pylori is due to null mutations in a gene $(r d x A)$ that encodes an oxygen-insensitive NADPH nitroreductase. Mol. Microbiol. 28: 383-393. http://dx.doi.org/10.1046/j.1365-2958.1998.00806.x

Hirayama Y, Kawai T, Otaki J, Kawakami K, et al. (2014). Prevalence of Helicobacter pylori infection with healthy subjects in Japan. J. Gastroenterol. Hepatol. 29: 16-19. http://dx.doi.org/10.1111/jgh.12795

Jenks PJ and Edwards DI (2002). Metronidazole resistance in Helicobacter pylori. Int. J. Antimicrob. Agents 19: 1-7. http://dx.doi.org/10.1016/S0924-8579(01)00468-X

Jeong JY, Mukhopadhyay AK, Dailidiene D, Wang Y, et al. (2000). Sequential inactivation of $r d x A$ (HP0954) and frxA (HP0642) nitroreductase genes causes moderate and high-level metronidazole resistance in Helicobacter pylori. $J$. Bacteriol. 182: 5082-5090. http://dx.doi.org/10.1128/JB.182.18.5082-5090.2000

Kansau I, Raymond J, Bingen E, Courcoux P, et al. (1996). Genotyping of Helicobacter pylori isolates by sequencing of PCR products and comparison with the RAPD technique. Res. Microbiol. 147: 661-669. http://dx.doi. org/10.1016/0923-2508(96)84023-X

Kwon DH, El-Zaatari FA, Kato M, Osato MS, et al. (2000). Analysis of $r d x A$ and involvement of additional genes encoding $\mathrm{NAD}(\mathrm{P}) \mathrm{H}$ flavin oxidoreductase (FrxA) and ferredoxin-like protein $(\mathrm{FdxB})$ in metronidazole resistance of Helicobacter pylori. Antimicrob. Agents Chemother. 44: 2133-2142. http://dx.doi.org/10.1128/AAC.44.8.21332142.2000

Maggi Solca N, Bernasconi MV, Valsangiacomo C, Van Doorn LJ, et al. (2001). Population genetics of Helicobacter pylori in the southern part of Switzerland analysed by sequencing of four housekeeping genes $(a t p D, \operatorname{gln} A, \operatorname{scoB}$ and $\operatorname{rec} A)$, and by vacA, cagA, iceA and IS605 genotyping. Microbiology 147: 1693-1707. http://dx.doi.org/10.1099/00221287$147-6-1693$

Martínez-Júlvez M, Rojas AL, Olekhnovich I, Angarica VE, et al. (2012). Structure of RdxA: an oxygen insensitive nitroreductase essential for metronidazole activation in Helicobacter pylori. FEBS J. 279: 4306-4317. http://dx.doi. org $/ 10.1111 /$ febs. 12020

Matteo MJ, Perez CV, Domingo MR, Olmos M, et al. (2006). DNA sequence analysis of $r d x A$ and frxa from paired metronidazole-sensitive and -resistant Helicobacter pylori isolates obtained from patients with heteroresistance. Int. J. Antimicrob. Agents 27: 152-158. http://dx.doi.org/10.1016/j.ijantimicag.2005.09.019

Mirzaei N, Poursina F, Moghim S, Rahimi E, et al. (2014). The mutation of the $r d x A$ gene in metronidazole-resistant Helicobacter pylori clinical isolates. Adv. Biomed. Res. 3: 90. http://dx.doi.org/10.4103/2277-9175.128469

Nguyen TL, Uchida T, Tsukamoto Y, Trinh DT, et al. (2010). Helicobacter pylori infection and gastroduodenal diseases in Vietnam: a cross-sectional, hospital-based study. BMC Gastroenterol. 10: 114. http://dx.doi.org/10.1186/1471230X-10-114

NIH Consensus Development Panel on Helicobacter pylori in Peptic Ulcer Disease (1994). NIH Consensus Conference. Helicobacter pylori in peptic ulcer disease. JAMA 272: 65-69.

Rimbara E, Sasatsu M and Graham DY (2013). PCR detection of Helicobacter pylori in clinical samples. Methods Mol. Biol. 943: 279-287. http://dx.doi.org/10.1007/978-1-60327-353-4_19

Scarpignato C (2004). Towards the ideal regimen for Helicobacter pylori eradication: the search continues. Dig. Liver Dis. 36: 243-247. http://dx.doi.org/10.1016/j.dld.2004.01.004

Shi R, Xu S, Zhang H, Ding Y, et al. (2008). Prevalence and risk factors for Helicobacter pylori infection in Chinese populations. Helicobacter 13: 157-165. http://dx.doi.org/10.1111/j.1523-5378.2008.00586.x

Sjunnesson H, Falt T, Sturegard E, Abu Al-Soud W, et al. (2003). PCR-denaturing gradient gel electrophoresis and two feces antigen tests for detection of Helicobacter pylori in mice. Curr. Microbiol. 47: 278-285. http://dx.doi. org/10.1007/s00284-002-3952-x

Solca NM, Bernasconi MV and Piffaretti JC (2000). Mechanism of metronidazole resistance in Helicobacter pylori: comparison of the $r d x A$ gene sequences in 30 strains. Antimicrob. Agents Chemother. 44: 2207-2210. http://dx.doi. org/10.1128/AAC.44.8.2207-2210.2000

Tankovic J, Lamarque D, Delchier JC, Soussy CJ, et al. (2000). Frequent association between alteration of the $r d x A$ gene and metronidazole resistance in French and North African isolates of Helicobacter pylori. Antimicrob. Agents Chemother. 44: 608-613. http://dx.doi.org/10.1128/AAC.44.3.608-613.2000

Tee W (1997). Ribosomal RNA gene restriction pattern analysis (Ribotyping) of H. pylori. Methods Mol. Med. 8: 89-98.

Uchida T, Miftahussurur M, Pittayanon R, Vilaichone RK, et al. (2015). Helicobacter pylori infection in Thailand: a nationwide study of the CagA phenotype. PloS One 10: e0136775. http://dx.doi.org/10.1371/journal.pone.0136775

Wisniewski RM and Peura DA (1997). Helicobacter pylori: beyond peptic ulcer disease. Gastroenterologist 5: 295-305.

Yang YJ, Wu JJ, Sheu BS, Kao AW, et al. (2004). The $r d x A$ gene plays a more major role than frxA gene mutation in high-level metronidazole resistance of Helicobacter pylori in Taiwan. Helicobacter 9: 400-407. http://dx.doi. org/10.1111/j.1083-4389.2004.00270.x

Genetics and Molecular Research 15 (3): gmr.15038674 